\title{
Building Learning Trajectory Mathematical Problem Solving Ability in Circle Tangent Topic by Applying Metacognition Approach
}

\author{
Fikri Mukasyaf ${ }^{1}$, Kms. M. Amin Fauzi ${ }^{1} \&$ Mukhtar $^{1}$ \\ ${ }^{1}$ State University of Medan (Unimed), Jl. Pasar V Medan Estate, Medan, Indonesia \\ Correspondence: Fikri Mukasyaf, School of Mathematics Education, State University of Medan, Indonesia. \\ E-mail: fmukasyaf@ymail.com
}

Received: July 6, 2018

doi:10.5539/ies.v12n2p109
Accepted: September 1, $2018 \quad$ Online Published: January 30, 2019

URL: https://doi.org/10.5539/ies.v12n2p109

\begin{abstract}
Mathematical problem solving ability is one of the most important abilities students must have to process the information provided in solving problems. Before using mathematical problem solving skills, prior knowledge becomes the most crucial thing that makes students able to connect all available information so that they can construct new knowledge through the process of assimilation or accommodation. The purpose of this reseach is to:(1) Analyze prior knowledge what student has so the student can solve the problem of tangent circle given; (2) Know how learning trajectory in student's mathematical problem solving ability by applying metacognition approach. This reaseacrch is a design research to improve the quality of learning. In this reseacrh researchers gave 3 test questions on students' mathematical problem solving abilities. One trial was conducted in class VIII-B and trial II was conducted in class VIII-A, each consisting of 30 students junior high school. The result of students answer analysis shows the mast problematic topic that makes the studnts are difficult to solve the problem is about the tangent cicrcle that is the elements of the circle and the concept of circle circumtance there are three phased in learning path of students mathematical problem solving skill that are under standing the problem, making the problem solving plan by prrior knowledge and doing problem solving and evaluating it. From this explanation, it is better for teachers to ensure students have sufficient prior knowledge to make it easier to construct new knowledge, as well as make the learning process fun and meaningful so that students will remember knowledge in long-term memory.
\end{abstract}

Keywords: mathematical problem solving skill, prior knowladge, circle tangent, metacognition approach

\section{Intoroduction}

Problem is a thing that all individuals will discover, both unconsciously they indicat that is a problem. Problem solving ability is important capital in solving and dealing with a problem. Problem solving should be one of the skills developed and thought in schools to home the thinking and reasoning skill. Hudojo (1988, p. 133) states that problem solving is an essential thing in mathematics because (1) the students become skilled in selecting relevant information, than analyzing it and finally re-exanning; (2) intellectual satisfaction will arise from within which is an intrinsic gift to students; (3) students' intellectual potential is increased and; (4) students learn how to make discoveries through the process of discovery. Charles, Lester, and O'Daffer (in Szetela \& Nicol, 1992) focused on solving mathematical problems from three aspects: (1) understanding problem; (2) planing mathematical problems; (3) solving the problem (answer the problem). Based on the research survey, the problem solving skills test on the tangent material of the circle concluded that the students' mathematical problem solving ability is still low. Of the 24 students, only $4(16.16 \%)$ students who achieve the minimum criterion value of mastery (KKM) that is equal to 70 .

The result of the problem solving test showed that some students could not write down how to calculate the exact length of the bicycle chain and the students only used the formula to find the outline of the two circle outer circles only and did not understand the problem well that the concept of the circumference of the circle was also needed to determine the length of the chain of the bike because the chain is wrapped around the two bike gear. Overall of the students' answers the most students understand the problem, but the ability of students is still low in indikotor problem-solving abilities that are plan completion and solve the problems given.

Schoenfeld (1992, p. 38) states that metacognition includes knowledge of the process of thinking, self-awareness and confidence and intuition. Aspects of metacognition can help students in solving problems. Why is that? 
because in the process of solving problems students need to monitor or monitor the thinking process such as how and why he did the solving step, whether the solving step is going well or there are obstacles that can encourage students to think of other alternatives or try to understand the problem again. This is in line with Setyadi, Subanji, and Muksar's (2016) research which states conceptually metacognition as the knowledge or awareness of one's thinking process, the ability to monitor and manage the thinking process and its thinking, and to evaluate the thinking process and its thought result. Similarly, Fauzi (2015) states that learning with a metacognitive skill approach is essential for developing students' skills in learning cognitive strategies, e.g. asking themselves, extending these applications, and gaining control of their self-awareness. Prior knowledge in the context of learning, can be interpreted as the initial ability of the learners who can serve as a benchmark to see how much behavior changes that occur after learners follow the process of learning. This formula does not indicate that pror knowledge is not only related to the knowledge aspect but also about the attitudes and experiences of the learners. And Othman, Mahmud, and Jaidi (2014) this study concluded that reading lesson using the metacognition strategy can help to enchance students with moderate level of understanding on expository texts to understand better and more efectively compared to conventional aproach.

Matsuda's study reveals that prior knowledge greatly influences the learning process (Matsuda et al., 2013, p. 1154). It's emphasized by Bringula et al. (2016, p. 2), which states prior knowledge in mathematics affects interaction with learning systems and demonstration abilities. From these results, it can be concluded that prior knowledge is important to build new knowledge of learners, and as an important initial capital in solving a problem so that the ability to solve mathematical problems can be created well.

Hypothectial Learning Trajectory (HLT) is an instrument that guides the process of conducting of research with reseaarch as an extension of thought experiment that is developed by frudental. According to Simon (in Bakker, 2003) states: hypothetical learning flow or hypothetical learning flow consists of three main components of learning objectives for meaningful learning, a set of tasks to achieve those goals, and hypotheses about how learners learn and how learners think. Learning objectives are meant here can be either understand a concept or solve a problem. According to Dahar (1991) problem solving is a human activity that combines the concepts and rules that have been obtained previously and it is not as a generic skill.

Circle tangent material requires prerequisite material to facilitate learners in understanding the material. The most influential material of the prerequisite is the concept of the circle. The prerequisite material is an initial knowledge that must be possessed by students in understanding the material of tangent of circle. Therefore it is true that the students' early ability is very influential in the learning process of students. Here is a preliminary design of the researcher about the learning flow of students in achieving the goal of understanding the material tangent of the circle.

Table 1. Initial design of hypothetical lerning trajectory circle tangent material

\begin{tabular}{llll}
\hline Topic & Priod 1 & Priod 2 & Priod 3 \\
\hline $\begin{array}{l}\text { Review the elements of } \\
\text { the circle }\end{array}$ & $\begin{array}{l}\text { Painted a tangent of a circle. As } \\
\text { follows: }\end{array}$ & $\begin{array}{l}\text { Determine the length the tangent line of } \\
\text { fellowship in two circles }\end{array}$ \\
$\begin{array}{l}\text { Circle } \\
\text { Tangent }\end{array}$ & $\begin{array}{l}\text { circumference of the } \\
\text { circle }\end{array}$ & $\begin{array}{l}\text { Determine the length the outline of the } \\
\text { outer alliance of two circles }\end{array}$ & on circle
\end{tabular}

Based on the above explanation researchers want to analyze what initial knowledge should be had learners to understand the material tangent of the circle. And what initial knowledge does the learner have so he has difficulty in understanding the tangent material of the circle. And researchers want to know how the trajectory of learning of ability problem solving of mathematical learners on the material tangent circle by using teaching materials that based on approach metacognistion. 


\section{Method}

\subsection{Subjects of The Research}

The subjects in this study were eighth grade students of Medan Imelda Middle School totaling 30 students for each class. The first trial was conducted in class VIII-B and Trial II in class VIII-A.

\subsection{Research Procedures and Research Design}

This research uses design research method with two trials as a way to answer the formulation of the problem so that the research objectives are achieved. Design research is a research method that aims to develop a local instructional theory through the collaboration of researchers with teachers to improve the quality of learning (Gravemeijer \& Van Eerde, 2009). A series of student activities consisting of a conjecture of students' strategies and thoughts will be developed in this study. This research will design activities based on student experience, namely activities that are familiar to eighth grade students of junior high school as an approach to understanding the tangent circle.This study consists of three stages with two trials that can be done repeatedly until a new theory is found which is the result of revisions of the learning theory that was tried. Following are the stages in research design.

\section{Phase I: Preliminary Design}

At this stage a literature study was carried out on square material and cube nets and a metaconitive approach so that a mathematical creative learning strategy and trajectory of students could be formed. Then proceed with a discussion between the researcher and the teacher about class conditions, research needs, schedule and method of conducting research with the teacher in question. At this stage learning trajectory and hypothetical learning trajectory are also designed. Then from local instructional theory formulated which consists of learning objectives. This conjecture aims as a guide to anticipate students' strategies and thoughts that emerge and develop in learning activities. Conjectures are dynamic and can be arranged and revised during the teaching process.

\section{Phase II: Teaching Experiment}

In this second stage is to try out teaching activities that have been designed in the first stage in the class. This trial aims to explore and hypothesize the strategies and thoughts of students during the learning process. During the process, the conjecture can be modified as a revision of the local instructional theory for the next activity. The teacher acts as a teacher and the researcher focuses on observing each activity and important moments during the trial process. At this stage a series of learning activities are carried out and the researcher observes and analyzes what happens during the learning process that takes place in the classroom.

\section{Phase III: Retrospective Analysis}

After testing the data obtained from learning activities in the classroom are analyzed and the results of this analysis are used to plan activities and to develop designs for subsequent learning activities. The purpose of retrospective analysis in general is to develop the level of local instructional theory. At this stage HLT is compared to actual student learning and from here can answer the problem formulation. Siklik Design Research (Gravemeijer, 2004) as follows.

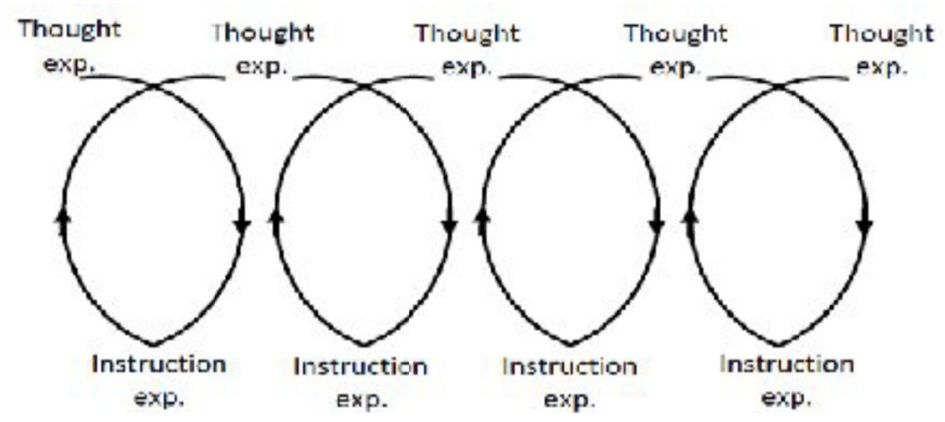

Figure 1. Cyclic process (Gravemeijer, 2004)

\section{Results and Discussion}

Before the pre-designed test materials and test instruments are tested, the teaching materials in the form of teacher books and student books and test instruments are validated by by 5 validators. Three validators were a mathematics 
doctor at the Medan State University and two other Mathematics teachers from the SMP Imelda Medan. Before being tested the ability to solve mathematical problem solving students are examined by the validator logically with the aim of knowing the logic and ease of language of the problem given. The assessment carried out by the validator on the test instrument of mathematical problem solving abilities includes indicators of content validity, language and problem writing, and recommendations. Validator results are shown in Table 2 below.

Table 2. The result of validation test of mathematical problem solving skill

\begin{tabular}{ccccc}
\cline { 3 - 4 } & & \multicolumn{3}{c}{ Assessment Validator For Item } \\
\cline { 3 - 5 } & Validator & \multicolumn{3}{c}{ Item } \\
\cline { 2 - 5 } & & 1 & 2 & 3 \\
\cline { 2 - 5 } Validator 1 & $\mathrm{TR}$ & $\mathrm{TR}$ & $\mathrm{TR}$ \\
Validator 2 & $\mathrm{TR}$ & $\mathrm{TR}$ & $\mathrm{TR}$ \\
Validator 3 & $\mathrm{RK}$ & $\mathrm{RK}$ & $\mathrm{RK}$ \\
Validator 4 & $\mathrm{TR}$ & $\mathrm{TR}$ & $\mathrm{TR}$ \\
& Validator 5 & $\mathrm{TR}$ & $\mathrm{TR}$ & $\mathrm{TR}$ \\
\hline
\end{tabular}

Note. TR: Not Revision; RK: Small Revisions

In Table 3 it shows the students' mathematical problem solving test of the five validators, four validators stated that the students' mathematical problem solving tests that designed can be used without revision. A validator stated that for item 1 is necessary to make a small revision, as well as to item 2 and 3 need to do a little revision. Beside validation by the validotor, test of students' mathematical problem solving abilities also conducted previous trials with validation value of each question shown in Table 3 below.

Table 3. Validity of problem solving problems with mathematical problem solving

\begin{tabular}{lcccc}
\hline Question Item & $r_{x y}$ & $t_{\text {observe }}$ & $t_{\text {table }}$ & Validation Level \\
\hline 1. & 0.790 & 6.816 & 2.048 & Valid \\
\hline 2. & 0.643 & 4.445 & 2.048 & Valid \\
\hline 3. & 0.752 & 6.029 & 2.048 & Valid \\
\hline
\end{tabular}

Based on Table 3, each value of $t_{\text {observe }}>t_{\text {table }}$ concluded that the test of mathematical problem solving ability was said to be valid. From the result of the students 'mathematical problem solving test in the first experimental test the average of students' mathematical problem solving ability on the problem understanding indicator is 1.92 , the troubleshooting plan indicator is 2.26 , and the problem solving indicator is 2.51 . While in trial II, the average of students' mathematical problem solving ability on the indicator of understanding the problem is 1.94 , the indicator of problem-solving plan is 2.44, and the problem solving indicator is 2.63. Seen in Figure 3 follow.

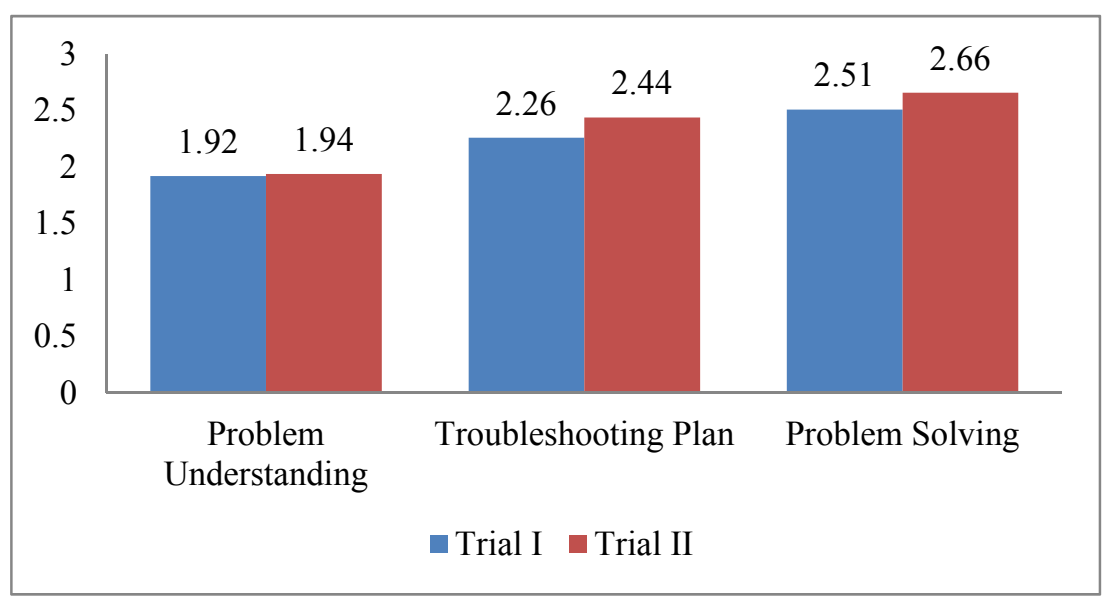

Figure 2. Average of mathematical problem solving capabilities 
In Figure 2, there was an increase in the students' mathematical problem solving ability on the problem-understanding indicator is 0.02 , the troubleshooting plan indicator is 0.18 , and the problem solving indicator is 0.12 . This shows the mathematical problem solving ability of students who are taught using teaching materials based on metacognition approaches have improved from trial I to trial II.

Building the trajectory of students' mathematical problem solving skills in the circle sophisticated tofic that is by analyzing the result of the test of mathematical problem solving ability that is done by the students. Here are the questions and solutions that students make:

\begin{tabular}{|c|c|}
\hline Soal & Jawaban siswa \\
\hline $\begin{array}{l}\text { Rahmad has an ontel bike. His } \\
\text { bicycle has a } 7 \mathrm{~cm} \text { the back } \\
\text { gear gear. And the front gear } \\
\text { radius } 14 \mathrm{~cm} \text {, and the distance } \\
\text { of both gear is } 50 \mathrm{~cm} \text {. Rahmad } \\
\text { wanted to calculate the length } \\
\text { of the minimum chain that must } \\
\text { be bought to be able to use his } \\
\text { bike. Help Rahmad to calculate } \\
\text { the length of the bicyle chain! }\end{array}$ & 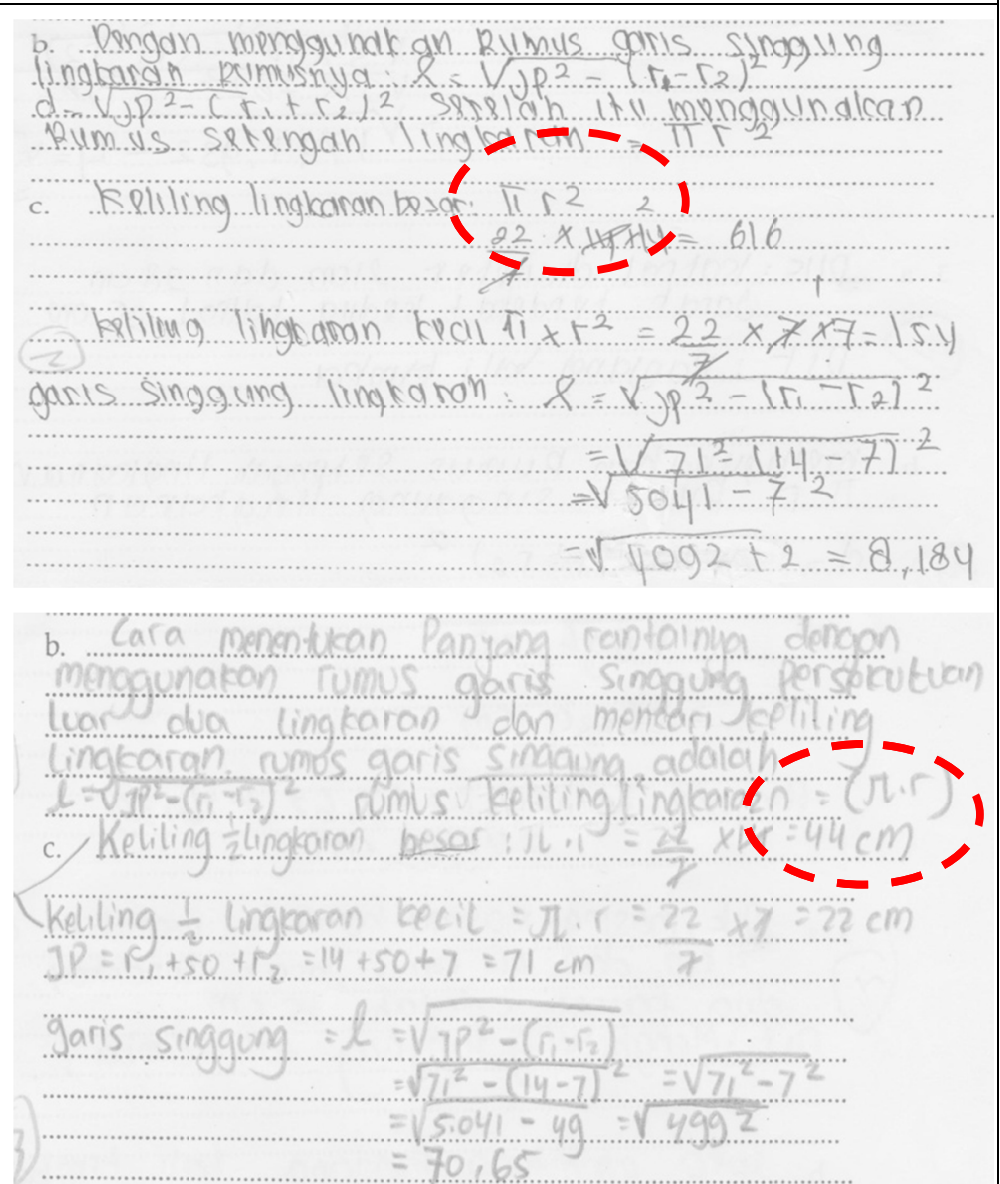 \\
\hline \multicolumn{2}{|c|}{$\begin{array}{l}\text { In the first finding on the step of making problem-solving planning } 17 \text { out of } 30 \text { students do not } \\
\text { understand the concept of the circumference of the circle. Student declares the circumference formula of } \\
\text { circle } \pi r^{2} \text { which is the formula of the large of the circle. It shows the students' early knowledge about the } \\
\text { concept of circle has not been good. While in the secound findings } 13 \text { out of } 30 \text { students mentioned in the } \\
\text { planning step of solving the problem of the circle } \pi \mathrm{r} \text { circumference formula, but in the step of solving the } \\
\text { problem of true students who declared the formula halfway around the circle } \pi \mathrm{r} \text {. }\end{array}$} \\
\hline $\begin{array}{l}\text { Udin works in a panglong. One } \\
\text { day the customer ordered } 3 \\
\text { pipes of water with the same } \\
\text { diameter } 6 \text { inch ( } 1 \text { inch }=2.54 \\
\mathrm{~cm}) \text {.Udin wanted to tie the pipe } \\
\text { so customer is easier to carry } \\
\text { the pipe. What is the minimum } \\
\text { length of rope Udin needed? }\end{array}$ & 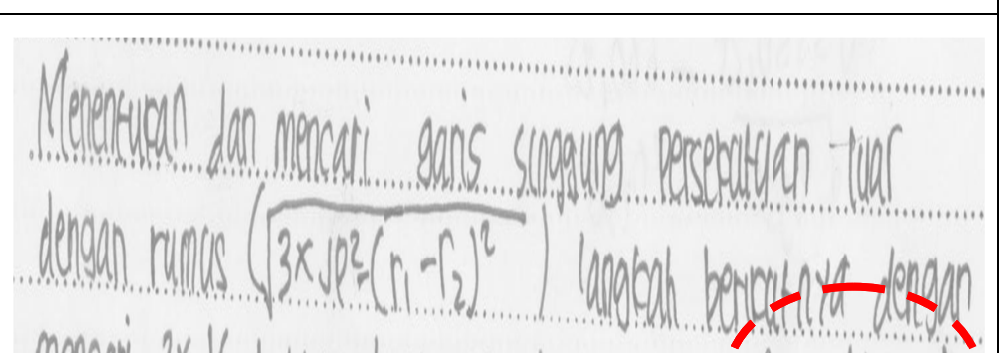 \\
\hline
\end{tabular}




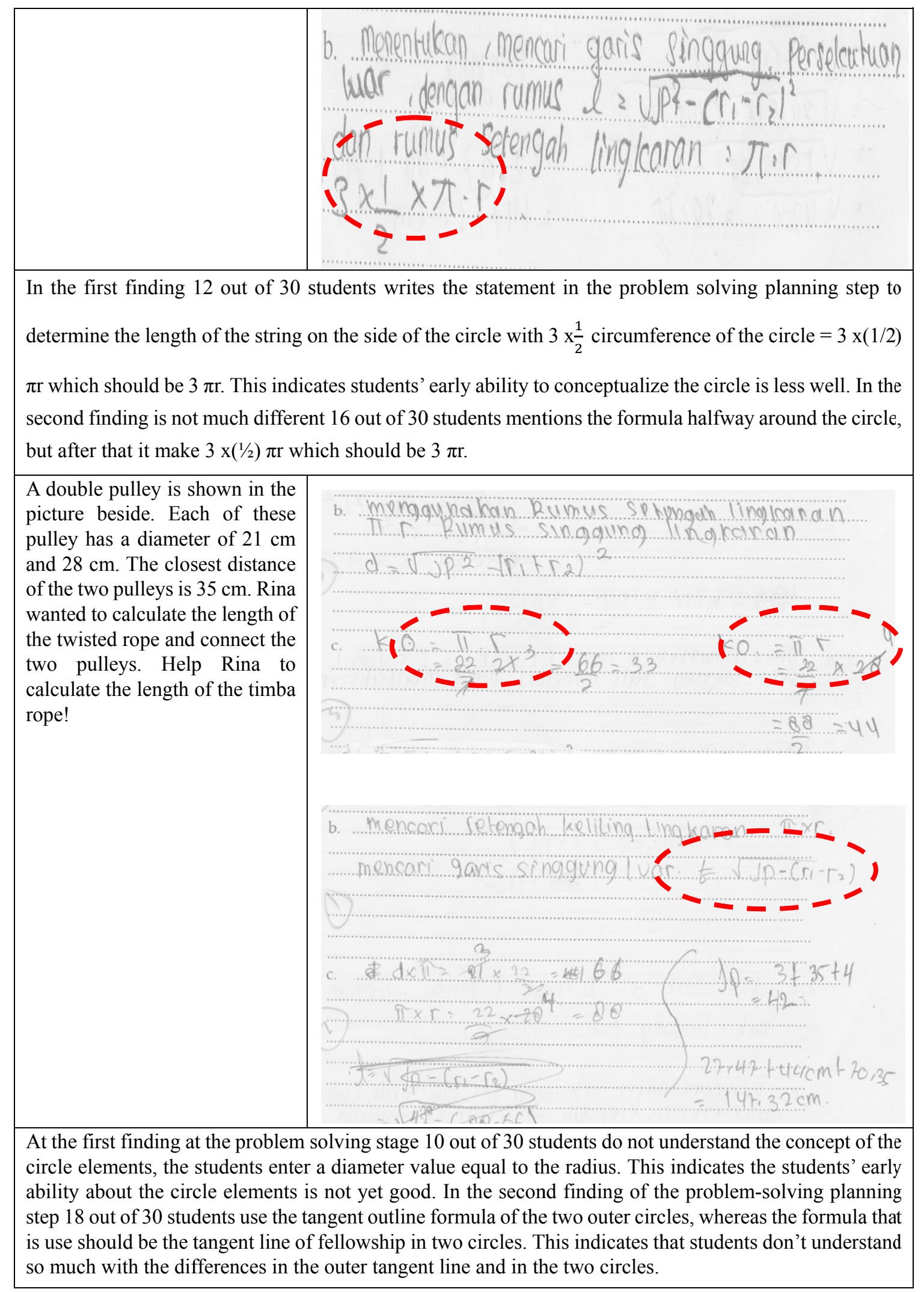

The track point of learning trajectory of student's problem solving as the findings of this research as much as 3 steps is to understand the problem, make a problem-solving planning by relying on its initial capability, as well as solving problems as well as evaluate the results of problem solving. Students activate their cognitive with overall metacognitive from planning, monitoring, and evaluating. This is in line with the results of the Memnun (2015) 
research that conclud that the mathematical problem solving ability of grade VI students is more successful than class V, which means that students' mathematical problem-solving ability is influenced from their cognitive level.

Metacognition is an idea of the self-contained mind, which includes one's awareness of what he knows (metacognitive knowledge), about what he can do (metacognitive skills), and what he knows about his own cognitive abilities (metacognitive experience). In the results of the students' answers, students activate their cognitive by relying on their initial abilities in answering the given problems, then they make the formula planning that will be used, and they do calculations based on their numeracy skills.

Hypotetical learning trajectory (HLT) in this study is learning goals by determining the goals to be achieved in the tangent material of the circle, namely students can determine the length of the rope wrapped around two circles, learning activity by designing student activities that can improve students' mathematical problem solving abilities tangent circle, hypotetical learning process by designing materials that can support students' thinking in reaching the tangent circle that is knowing the elements of the circle and the concept of broad and circumferential circles, and teacher support by relying on the teacher's ability to apply learning with a metacognition approachIn this case the researcher adds teacher support (help and direction from teacher) as component of HLT. Because according to the researcher in the process of learning assistance and direction of the teacher is of needed at the learning process especially for students who have low ability.

In mathematics learning, as if are climb up the stairs, if one step is missing it is difficult for us to reach the goal, further more two steps lost so we will be more difficult to climb up. That's the learning of mathematics a concept that one with the other has a relationship, to understand the next concept so we must know the previous concept. Therefore, the role of educators is also needed in activating cognitive of students. Arranging of hypotetical learning trajectory must really be done to anticipate what mental activities should be and what knowledge should be possessed by students in understanding a concept in mathematics.

Prior knowledge that is less good causes students difficult to connect each information, manage it, and present the given problem. Before students understand the lines of a circle the students are trained to paint the tangents of the two-circle fellowship. And the initial knowledge that students must be had to solve the problems about the length of the circle of circle is the circle elements, the wide and circumference of the circle, the position of the line on the circle, the length of the tangent alliance of two circles. The full path can be seen in Table 4 below.

Table 4. Hypothetical lerning trajectory circle tangent material

\begin{tabular}{|c|c|c|c|c|}
\hline Period & Priod 1 & Priod 2 & Priod 3 & Priod 4 \\
\hline Topic & \multicolumn{4}{|c|}{ Circle Tangent } \\
\hline Sub topic & the elements of the circle & $\begin{array}{l}\text { Large and circumference of } \\
\text { circle }\end{array}$ & tangent of two-circle fellowship & Length of coil \\
\hline \multirow[t]{2}{*}{$\begin{array}{c}\text { Learning } \\
\text { activity plan }\end{array}$} & $\begin{array}{l}\text { Review the elements of the } \\
\text { circle } \\
\text { Mention the elements of the } \\
\text { circle }\end{array}$ & $\begin{array}{l}\text { Understand the broad } \\
\text { formula of the circle }\end{array}$ & $\begin{array}{l}\text { Painting tangent of two-circle } \\
\text { fellowship } \\
\text { Determining the length of the } \\
\text { outer crossword of the two } \\
\text { circles }\end{array}$ & $\begin{array}{l}\text { Determine The length of } \\
\text { the rope around the circle }\end{array}$ \\
\hline & $\begin{array}{l}\text { Understand the meaning of } \\
\text { the existing part of the circle }\end{array}$ & $\begin{array}{l}\text { Understand the } \\
\text { circumference formula of } \\
\text { the circle }\end{array}$ & $\begin{array}{l}\text { Determine the length of the } \\
\text { tangent Alliance in two circles }\end{array}$ & \\
\hline
\end{tabular}

\section{Conclusions}

From the student's answer in answering the problem of determining the length of the string that wrapped around several circles using the concepts of a two-circle parallelism circle and the circumference of the circle, some students still have not been able to solve the given problems. Students can not plan for problem solving well, due to lack of prior knowledge of students. Prior knowledge of students that make students difficult to solve the problem of tangent circle is the elements of the circle and the concept of the circumference of the circle. There are 3 phases in the learning path of students' mathematical problem solving skills, that are understanding the problem, making the problem-solving plan by prior knowledge, and doing problem solving and evaluating it. Based on these conclusions, educators should ensure that students understand the concepts of a material before continuiting to the next material that requires the concept of the previous material, so that students have sufficient initial knowledge in solving the given problems. Educators should be able to create a fun and meaningful learning atmosphere and 
orientate the contextual problem in the students' mind.

\section{References}

Bakker, A. (2003). Design Research in Statistics Education on Symbolizing and Computer Tools. Amersfoort: Wilco Press.

Bringula, R. P., Basa, R. S., Dela Cruz, C., \& Rodrigo, M. M. T. (2016). Effects of Prior knowledge in mathematics on learning-interface interaction in a Learning-by-teaching intelligent tutoring system. Journal of Educational Computing Research, 54(4), 462-482. https://doi.org/10.1177/0735633115622213

Dahar, R. W. (1991). Teori-teori Belajar. Jakarta: P2LPTK Dirjen Dikti Depdikbud.

Fauzi, A. (2015). The Enhancement of Student's Mathematical Connection Ability and Self regulation learning with Metacognitive Learning Approach in Junior High School. International Conference on Research and Education in Mathematics (ICREM7).

Gravemeijer, K., \& Van Eerde, D. (2009). Design Research as a Means for Building a Knowledge Base for Teaching in Mathematics Education. The Elementary School Journal, 109(5), 510-524. https://doi.org/10.1086/596999

Gravemeijer, K. (2004). Local Instructional Theories as Means of Support for Teacher in Reform Mathematics Education. Mathematical Thinking and Learning, 6(2), 105-128. Lawrence Erlbaum Association, Inc. https://doi.org/10.1207/s15327833mt10602_3

Hudojo, H. (1988). Pengenbangan Kurikulum dan Pembelajaran matematika. Malang: Universitas Negeri Malang (UM PRESS).

Matsuda, N., Yarzebinski, E., Keiser, V., Raizada, R., Cohen, W. W., Stylianides, G. J., \& Koesinger, K. R. (2013). Cognitive anatomy of tutor learning: Lessons learne with SimStudent. Journal of Educational Psychology, 105(4), 1152. https://doi.org/10.1037/a0031955

Memnun. (2015). Mathematical Problem Solving: Variables that Affect Problem Solving Success. International Research in Education, 2(3).

Othman, Y., Mahmud Z., \& Jaidi, N. (2014). The Effects of Metacognitive Strategy in Reading Expository Text. International Education Studies, 7(13), 102-111. https://doi.org/10.5539/ies.v7n13p102

Schoenfeld, A. H. (1992). Learning To Think Matematically: Problem Solving, Metacognition, And Sense-Making in Mathematics. In D. Grouws (Ed.), Handbook for Research on Mathematics Teaching and Learning (pp. 334-370).

Setyadi, D., Subanji, \& Muksar, M. (2016). Identification of Students' Metacognition Level in Solving Mathematics Problem about Sequence (Vol. 6).

Szetela, W., \& Nicol, W. (1992). Evaluating problem solving in mathematics. New York: Cambridge University Press.

\section{Copyrights}

Copyright for this article is retained by the author(s), with first publication rights granted to the journal.

This is an open-access article distributed under the terms and conditions of the Creative Commons Attribution license (http://creativecommons.org/licenses/by/4.0/). 